\title{
Quantification of Potentially Toxic Elements in Degraded Mining Soils and Medicinal Plants: A Case Study of Indus Kohistan Region Northern Pakistan
}

\section{Waseem sardar}

Kangwon National University

\section{Aziz Ur Rahman}

University of Veterinary and Animal Sciences

javed nawab ( $\sim$ javednawab11@yahoo.com )

Abdul Wali Khan University Mardan

\section{Sardar Khan}

University of Peshawar

Abid Ali

Abdul Wali Khan University

Zia Ur Rahman

Abdul Wali Khan University Mardan

Shams Ali Baig

Abdul Wali Khan University Mardan

Muhammad Qayash Khan

Abdul Wali Khan University Mardan

\section{Research Article}

Keywords: Potentially toxic elements, Medicinal plants, Health risk, Plant uptake, Chromite mining

Posted Date: July 29th, 2021

DOI: https://doi.org/10.21203/rs.3.rs-217148/v1

License: (c) (i) This work is licensed under a Creative Commons Attribution 4.0 International License. Read Full License 


\section{Abstract}

In recent years, a series of environmental and ecological problems have occurred due to enhanced anthropogenic disturbances for precious minerals mining. Traditional medicines have become an important pillar in national homeopathic treatment system especially in mountainous environment of developing countries. The current study investigates the level of potentially toxic elements (PTEs ) contamination in degraded mining soil and medicinal plants along the mafic-ultramafic rocks in the Kohistan region. Soil samples and medicinal plant species were collected from the degraded mining area and were screened for PTEs ( $\mathrm{Pb}, \mathrm{Cr}, \mathrm{Ni}, \mathrm{Mn}, \mathrm{Zn}$, and $\mathrm{Cd}$ ) using atomic absorption spectrometry. Various pollution indices were used for PTEs such as contamination factor (CF), pollution load index (PLI) and translocation factor (TF) in degraded mining soil and medicinal plants. The mean concentration of PTEs found in soil were in order of $\mathrm{Mn}>\mathrm{Ni}>\mathrm{Cr}>\mathrm{Pb}>\mathrm{Zn}>\mathrm{Cd}$, while in medicinal plants were $\mathrm{Pb}>\mathrm{Cr}>\mathrm{Mn}>\mathrm{Ni}>\mathrm{Zn}>\mathrm{Cd}$. Highest bioaccumulation was observed in Ajuga bracteosa ( $\mathrm{Cr}=349 \mathrm{mg} \mathrm{kg}-1$ ), Phlomis bracteosa $(\mathrm{Pb}=335 \mathrm{mg} \mathrm{kg}-1)$, Chenopodium ambrosioides $(\mathrm{Mn}=304.3 \mathrm{mg} \mathrm{kg}-1)$, Isatis costata $(\mathrm{Ni}=169 \mathrm{mg} \mathrm{kg}$ $-1)$, Ajuga parviflora $(\mathrm{Zn}=38.4 \mathrm{mg} \mathrm{kg}-1)$ and Salvia moorcoftiana $(\mathrm{Cd}=11 \mathrm{mg} \mathrm{kg}-1)$. Furthermore, the concentrations of PTEs were significantly higher $(p<0.001)$ in degraded mining soil and medicinal plants than the reference site, which may be attributed to the mining and open dumping of mining wastes. The present study revealed that chromite mining and open dumping of mining wastes can cause serious environmental problem in the study area. Furthermore, medicinal plants grown in degraded mining soil may pose risk to the local inhabitants as most of the people consume these plants for various health problems.

\section{Introduction}

Contamination of soil ecosystem with potentially toxic elements (PTEs), like mercury ( $\mathrm{Hg})$, chromium ( $\mathrm{Cr}$ ), manganese $(\mathrm{Mn})$, lead $(\mathrm{Pb})$, cadmium $(\mathrm{Cd})$, zinc $(\mathrm{Zn})$ and nickel $(\mathrm{Ni})$ is one of the major environmental issues (Lajayer et al. 2017). Mining and metallurgical activities, such as excavation, transporting, smelting and various kinds of other industrial beneficiation processes have released a huge amount of PTEs into the nearby environment (Wang et al. 2019). These elements are persistent, cumulate latent, and cause irreversible damage to the soil ecosystem (Zeng et al. 2020). Once PTEs are released into the natural environment, they are accumulated by the surrounding crops, vegetables and other plants (Shen et al. 2017). The factors that affect the accumulation of PTEs in plants involve atmospheric depositions, the bioavailability of PTEs in soil, the physicochemical properties of soil ( $\mathrm{pH}$, texture and organic matter content) and the place where the plants are grown (Sadhu et al. 2015). In particular, plants growing on mafic-ultramafic rocks or near chromite mining areas have more potential for PTE accumulation (Nawab et al. 2016a,b; Nawab et al. 2015a,b; Zhao et al. 2014). Indeed, the industrialization of the last decades has led to advancement in medical sciences, but modern medicines manufactured by multinational companies in most cases do not satisfy the requirements of the majority population that reside in developing countries, such medicines are sometimes neither easily available nor affordable by the poor people. In such case conventional health care systems based on therapeutic herbs only remain a choice 
of routine medication, because it is easily accessible and affordable alternatives for many low-income people (Okatch et al. 2012). The World Health Organization (WHO) reported that $80 \%$ of under developed nations in the world still depend on traditional medicines, most of which are plant based drugs (Shen et al. 2017). Like other developing countries, Pakistan is also gifted with a wealth of medicinal plants. Pakistan has a unique biodiversity, varied climatic zones and soil conditions, and different ecological regions due to which the country has a very rich flora (Ali et al. 1986). According to an estimate, about 3,200 plant species having therapeutic effects are available in Pakistan (Muhammad et al. 2012). Pakistan locally trades about 200 herbal medicine and widely export 75 crude medicinal herbs and about $85 \%$ of these crude herbs are obtained from the forest by local people (Shinwari et al. 2011; Hazrat et al. 2010). People of rural areas still depend on the traditional system of medicines for their primary health care problems and as a source of income for poor residents, dealers and exporters (Shinwari et al. 2003). Furthermore, $25 \%$ of recent medicine are extracted from plants and their chemical analogs are synthesized to make modern drugs (Sadhu et al. 2015). Although the benefits obtained from medicinal plants are well established but the toxicity associated with their use may not be denied (Okatch et al. 2012). Several studies have shown the adverse effects of herbal medicines contaminated with PTEs (Okem et al. 2014). Moreover, Asian traditional medicine has been described to contain a high concentration of PTEs such as lead, mercury, and arsenic (Okatch et al. 2012). After collecting and changing into dosage the PTEs present in plants enters into the human body and affect the normal functions resulting in high blood pressure, intestinal ulcer, abdominal pain, skin diseases, and different types of cancer (Khan et al. 2008). Similarly, PTEs are not only harmful to humans but also affect plants even at low concentrations (Lajayer et al. 2017). For instance in plants, $\mathrm{Pb}$ and Cd can produce cell membrane lipid peroxidation, photosynthesis inhibition, nutrient imbalance, and subsequent yield reduction (Zeng et al. 2020). The quality and safety of medicinal plants are great concerns globally due to increasing PTEs contamination caused by anthropogenic activities, thus the screening of medicinal plants for potentially harmful metals has been recommended to protect the health of consumers (Okem et al. 2014). To date, in the study area, medicinal plants are freely sold in the open-air markets, at fairs, and especially by herbal vendors in the streets with little or no restriction. Based solely on traditional knowledge, the herb sellers or companies marketing medicinal plants do not perform screening for PTEs and also not provide any information on the maximum daily dosage that can cause toxicity in children, adults and old age people. Further, this data will play vital role for informing the public and government regularity authorities about the current problems and will influence to move forward in minimizing open dumping of mining wastes and its associated adverse impacts on local environment.

On the basis of the aforementioned issues, the current study investigated the concentration of PTEs in degraded mining soils and medicinal plants collected from the degraded mining areas in northern parts of Pakistan. The additional goal was to estimate the contamination degree and enrichment for medicinal plant species that either exceeded the safe limits in terms of PTEs contamination or not.

\section{Materials And Methods}

\section{Study area}


Kohistan district is in Northern Pakistan having latitude $34.90^{\circ}$ to $35.86^{\circ} \mathrm{N}$ and longitude $72.71^{\circ}$ to $73.95^{\circ} \mathrm{E}$ (Fig 1). The district boundary is surrounding on North-East by Diamir and Gizar districts, on South by Batagram while on the west by two districts Shangla and Swat. Its total population is approximately $<0.25$ million while having an area of $1800 \mathrm{~km}^{2}$. Kohistan is a mountainous region, and its inhabitants depend on agriculture. Geologically, the area is distinctive as it consists of three different rocks such as the Kohistan island arc, the Indian plate, and the Indus suture zone. These various rocks have a different composition from mafic to ultramafic and have several kinds of metallic and nonmetallic mineral deposits including huge deposits of chromite mining (Muhammad et al. 2011). This area was selected because the flora of the area is rich with medicinal herbs and most of the population uses these herbs for various health-related problems.

\section{Reagents and solutions}

All reagents used in the experiment were of analytical grade (Merck). HPLC grade water was used for the preparation and dilutions of stock solutions. Chemically pure grade hydrochloric acid $(\mathrm{HCl})$, nitric acid $\left(\mathrm{HNO}_{3}\right)$ and analytical reagent grade hydrofluoric $(\mathrm{HF})$ acid was used for metal digestion. Metals stock solutions of $(1000 \mathrm{mg} / \mathrm{L})$ were prepared for analysis.

\section{Sample collection}

A total of 27 medicinal plant species were collected from chromite mining sites and the surrounding area. Plants up to a height of $<1 \mathrm{~m}$ were uprooted and stored in polyethylene bags. Degraded mining soil sample of $1 \mathrm{~kg}$ from the upper horizon $(0-20 \mathrm{~cm})$ of each uprooted plant was collected and properly labeled. For reference, plants and soil samples were also collected $10 \mathrm{~km}$ away from the study area. The detail information is provided in the supporting information (SI). After bringing to the laboratory plant species were identified and classified by a taxonomist in the center of plants and biodiversity, University of Swat.

\section{Degraded mining soils sample pre-treatment and microwave digestion}

Degraded mining soil samples were air-dried and screen through a $2 \mathrm{~mm}$ mesh and stored in a paper envelope at room temperature. Soil $<2 \mathrm{~mm}$ fraction was also analyzed for physicochemical parameters such as $\mathrm{pH}$, soil organic matter (SOM), and electric conductivity (EC), according to the standard procedures. For the determination of PTEs wet digestion method (WDM) was used (Muhammad et al. 2011). Dried samples of $1 \mathrm{~g}$ were taken in a beaker with a mixture of hydrofluoric and hydrochloric acid (1:4) and heated approximately $130-140{ }^{\circ} \mathrm{C}$ for digestion. After full evaporation of acid, the concentrate was re-dissolved in diluted $\mathrm{HCl}$, subsequently filtered and diluted with milli-Q water to a final volume of $100 \mathrm{~mL}$ for analysis.

\section{Medicinal plants sample pre-treatment and microwave digestion}


All medicinal plants were thoroughly rinsed with milli-Q water and dried in an oven at a temperature between $60^{\circ} \mathrm{C}$ to $70{ }^{\circ} \mathrm{C}$ for 72 hours and were ground by an electric grinder. For extraction of PTEs briefly, $1.0 \mathrm{~g}$ of powdered samples were treated in a mixture of $\mathrm{HNO}_{3}$ and $\mathrm{HCl}(2: 5)$ and heated at about $180^{\circ} \mathrm{C}$ for digestion. After complete digestion and cooling, the concentrate was re-dissolved in diluted $\mathrm{HCl}$, subsequently filtered and diluted with Milli-Q water to a final volume of $100 \mathrm{~mL}$ for analysis.

\section{Quality control and quality assurance}

For quality assurance and quality control of PTEs in reference and degraded mining soil samples, certified reference materials (GBW-07406 (GSS-6)) were purchased from National Research Centre for Certified Reference Materials, China). The reference standards were used to compare the contents of PTEs in control and degraded mining soils, using Atomic Absorption Spectrophotometer (AAS-

PerkinElmer, 2380). Analytical precision was obtained using the standard deviation/mean. The accuracy was estimated via standard values in percentage recovery. Triplicate sub samples were analyzed to ensure the quality of results. AAS was calibrated with the blank sample and standards. For this purpose, a standard curve was obtained by plotting standard concentrations against absorbance. For accurate results, the standard was run after the analysis of every ten samples.

\section{Instrumental analysis}

Flame Atomic Absorption Spectrophotometer (AAS-PerkinElmer, 2380) was used for the detection of PTEs. Working standards of different concentrations were prepared to analyze each toxic element. A six-point calibration curve with the linearity of $r 2>0.999$, were obtained for quantification of PTEs.

\section{Pollution level quantification}

Pollution quantification was carried out by calculation of contamination factor (CF), pollution load index (PLI), and plant translocation factor (TF).

\section{Contamination factor (CF)}

The CF was calculated using the following equation.

$\mathrm{CF}=[\mathrm{C}] \mathrm{PTEs} /[\mathrm{C}]$ background

Where [C] PTEs means the concentration of PTEs in the contaminated soil and [C] background means the concentrations of PTEs in the reference site (Nawab et al. 2015a).

\section{Pollution load index (PLI)}

For the whole sampling site, $\mathrm{PLI}$ has been evaluated as the $\mathrm{n}^{\text {th }}$ root of $\mathrm{CF}$, according to the following equation (Nawab et al. 2015b). 


$$
\mathrm{PLI}=\sqrt[n]{C F 1 \times C F 2 \times C F 3 \times \ldots . C F n}
$$

PLI provides the comprehensive status of PTEs level in the study area.

\section{Translocation factor (TF)}

The plant TF was obtained by using the following equation (Nawab et al. 2015a).

$\mathrm{TF}=\mathrm{C}[\mathrm{PTEs}$ in plant $] / \mathrm{C}[\mathrm{PTEs}$ in soil $]$

\section{Statistical analyses}

The results of mean, standard deviation and ranges were obtained by using Excel 2016 (Microsoft Office) while co-relation coefficient and one-way ANOVA were analyzed by using SPSS (21) version.

\section{Results And Discussion}

\section{Physicochemical parameters of degraded mining soil}

Table 1 and Table S1 (Supporting Information) show the physicochemical parameters of the soil samples collected from reference and contaminated sites. The mean values of $\mathrm{pH}, \mathrm{EC}$ and SOM were 7.6, $225 \mu \mathrm{S}$ $\mathrm{cm}^{-1}$ and $1.68 \%$, respectively. In this study, the $\mathrm{pH}, \mathrm{EC}$ and SOM values were observed lower than those reported by Muhammad et al. (2013). Similarly, Table 2 summarizes the range and mean concentrations of PTEs in soils collected from reference and contaminated site (degraded mining soils) (details are provided in Table S2 S3). The concentrations of $\mathrm{Zn}, \mathrm{Mn}, \mathrm{Pb}, \mathrm{Ni}, \mathrm{Cd}$ and $\mathrm{Cr}$ in degraded mining soils samples ranged from $9.5-261.6 \mathrm{mg} \mathrm{kg}^{-1}, 387.3-956 \mathrm{mg} \mathrm{kg}^{-1}, 16-633.2 \mathrm{mg} \mathrm{kg}^{-1}, 200-1008 \mathrm{mg} \mathrm{kg}^{-1}$, $1-16 \mathrm{mg} \mathrm{kg}^{-1}$ and $90-1751 \mathrm{mg} \mathrm{kg}^{-1}$, respectively. The concentration of these toxic elements was recorded in order of $\mathrm{Cr}>\mathrm{Ni}>\mathrm{Mn}>\mathrm{Pb}>\mathrm{Zn}>\mathrm{Cd}$. The permissible limit set by SEPA (1995) for $\mathrm{Zn}, \mathrm{Pb}, \mathrm{Ni}, \mathrm{Cd}$, and $\mathrm{Cr}$ is $300 \mathrm{mg} \mathrm{kg}^{-1}, 350 \mathrm{mg} \mathrm{kg}^{-1}, 60 \mathrm{mg} \mathrm{kg}^{-1}, 0.7 \mathrm{mg} \mathrm{kg}^{-1}$ and $250 \mathrm{mg} \mathrm{kg}^{-1}$ respectively (Shen et al. 2017). The level of PTEs in the degraded mining soil samples of the study area was found higher than the permissible limit. These high concentrations of PTEs in soil samples are due to the presence of maficultramafic rocks, chromite deposits in the study area (Nawab et al. 2015a). Several studies of mining areas have reported higher PTE concentrations in soil (Shen et al. 2017). In this study, the concentrations of $\mathrm{Pb}, \mathrm{Zn}, \mathrm{Mn}$ and $\mathrm{Cd}$ were found higher, while $\mathrm{Ni}$ and $\mathrm{Cr}$ were found lower than those reported by Muhammad et al. (2013).

\section{Contamination factor (CF) and pollution load index (PLI) in degraded mining soil}

Table 2 show the CF and PLI values of degraded mining soils collected from the Kohistan region. A method developed by Muler, (1969) was used for pollution CF and PLI to evaluate the levels of PTEs pollution in the soil collected from degraded mining areas. The value of $\mathrm{CF}$ for $\mathrm{Zn}$ (3.44), $\mathrm{Mn}$ (1.71), $\mathrm{Pb}$ (8.96), $\mathrm{Ni}$ (15.51), $\mathrm{Cd}$ (18.26) and $\mathrm{Cr}$ (15.22) are presented in table 2. The CF values were found in order of 
$\mathrm{Cd}>\mathrm{Ni}>\mathrm{Cr}>\mathrm{Pb}>\mathrm{Zn}>\mathrm{Mn}$ in soil collected from degraded mining areas. According to Muler (1969) classification, the area is highly polluted by $\mathrm{Cd}, \mathrm{Ni}, \mathrm{Cr}$ and $\mathrm{Pb}$ while moderately polluted by $\mathrm{Zn}$ and $\mathrm{Mn}$. The PLI was also calculated as the mean of the CF for $\mathrm{Zn}, \mathrm{Mn}, \mathrm{Ni}, \mathrm{Pb}, \mathrm{Cd}$ and $\mathrm{Cr}$ as shown in table 2. The PLI value (7.81) indicated a high level of pollution in degraded mining soil. This higher PLI values may be attributed to the presence of mafic-ultramafic rocks and chromite deposits, which may create serious health-related issues for humans and the environment. The CF and PLI values determine in this study were found higher than those reported by (Muhammad et al. 2013).

\section{Contamination factor (CF) and translocation factor (TF) in medicinal plants}

Tables 3 and Table 5 show the PTEs contamination factor and TF values in medicinal plants collected from the Kohistan region. Among the selected plant species CF values for $\mathrm{Zn}, \mathrm{Mn}, \mathrm{Pb}, \mathrm{Ni}, \mathrm{Cd}$ and $\mathrm{Cr}$ were $0.95,9.7,4.8,5.41,10.08$ and 11.37, respectively. As compared to the reference site, higher CF values were found in plant species of the study area, indicating that the study area is extremely polluted. These higher CF values in the study site may be influenced by extensive mining and open dumping of waste in the surrounding area. Plant TF values were calculated for $\mathrm{Pb}, \mathrm{Zn}, \mathrm{Ni}, \mathrm{Mn}, \mathrm{Cd}$ and $\mathrm{Cr}$ from soil to plants which were observed highest in plants species like Phlomis bracteosa $\left(\mathrm{Zn}=1.79 \mathrm{mg} \mathrm{kg}^{-1}\right)$, Chenopodium ambrosioides $\left(\mathrm{Mn}=0.62 \mathrm{mg} \mathrm{kg}^{-1}\right)$, Rumexha status $\left(\mathrm{Pb}=13.5 \mathrm{mg} \mathrm{kg}^{-1}\right)$, Isatis costata $\left(\mathrm{Ni}=0.51 \mathrm{mg} \mathrm{kg}^{-1}\right)$, Conyzasp and Sonchus arvensis $\left(\mathrm{Cd}=7 \mathrm{mg} \mathrm{kg}^{-1}\right)$ and Chenopodium ambrosioides $(\mathrm{Cr}=1.13 \mathrm{mg} \mathrm{kg}$

$\left.{ }^{1}\right)$. These high TF values in plant species indicated that they are good metal accumulators and can be used for phytoremediation. PTE concentrations were higher in mining soil as compared to plants, and the TF values were almost above in all plant species. This high level of TF values may be due to the physicochemical parameters of the soils (Nawab et al. 2015a).

\section{PTEs concentration in medicinal plants}

A total of 27 medicinal plant species belong to 13 families were classified in the study area, which were used for the treatment of several types of human diseases. The detail about its medicinal values are summarized in Table 4. Similarly, the concentration of $\mathrm{Zn}$ in the selected medicinal plants ranged from 5.5-38.4 $\mathrm{mg} \mathrm{kg}^{-1}$. The highest mean concentration of $\mathrm{Zn}$ was detected in Ajuga parviflora and the lowest in onosma (Table 5). The high amount of Zn not only cause adverse effects on human but also inhibits the growth of root and shoots in plants (Nawab et al. 2015b). The concentration of Mn in medicinal plants ranged from $20-304.3 \mathrm{mg} \mathrm{kg}^{-1}$. The maximum concentration of $\mathrm{Mn}$ was detected in Chenopodium ambrosioides and the minimum in plantago lanceolata (Table 5). The high accumulation rate of $\mathrm{Mn}$ in plant leaves affects photosynthesis, other common symptoms of Mn phyto-toxicity are necrotic brown spotting on stems leaves and petioles (Nawab et al. 2015a). The concentration of Pb in medicinal plants ranged from 4-335 (mg kg-1). The maximum concentration of $\mathrm{Pb}$ was observed in Phlomis bracteosa and the minimum in Ajuga parviflora. Pb is a toxic element for living organisms, it causes a headache, muscle aches, nausea, constipation fatigue and anemia, it also affects bones, kidneys and the central nervous system (Rehman et al. 2013). The concentration of Ni in medicinal plants ranged from 24-169 $\mathrm{mg} \mathrm{kg}^{-1}$. The highest concentration of Ni was detected in Isatiscostata and the 
lowest in Varbascum Thapus (Table 5). The most common adverse effect of $\mathrm{Ni}$ is contact dermatitis also known as nickel itch, which mostly occurs in moist skin. Moreover, Ni has been recognized as a carcinogen and affects nasal cavities and lungs (Khan et al. 2008). The concentration of Cd in medicinal plants ranged from 1-11 $\mathrm{mg} \mathrm{kg}^{-1}$. The highest concentration of Cd was found in Salviamo orcoftiana and the lowest in Varbascum Thapus, Indigofera heterantha and Limoniom cabulicum. Cd causes many health problems in living organisms it causes both acute and chronic toxicity, adverse effects on the liver, kidney, immune and vascular system (Jabeen et al. 2010). The concentration of $\mathrm{Cr}$ in medicinal plants ranged from 39-349 $\mathrm{mg} \mathrm{kg}^{-1}$. The highest concentration of $\mathrm{Cr}$ was found in Ajuga bracteosa and the lowest in Stachysemodi. Hexavalent $\mathrm{Cr}$ is a skin and mucous membrane irritant (Rehman et al. 2013). The maximum allowable limits of $\mathrm{Pb}, \mathrm{Cd}, \mathrm{Ni}$ and $\mathrm{Cr}$ in plants set by WHO /FAO (1984) is $0.3 \mathrm{mg} \mathrm{kg}^{-1}, 0.1$ $\mathrm{mg} \mathrm{kg}^{-1}, 66.9 \mathrm{mg} \mathrm{kg}^{-1}$ and $2.3 \mathrm{mg} \mathrm{kg}^{-1}$,respectively (Khan et al. 2015). Our study revealed that PTEs concentration in all medicinal plants were above the permissible limit which is a matter of high concern for public safety. In this study, the $\mathrm{Mn}, \mathrm{Pb}, \mathrm{Ni}, \mathrm{Cd}$ and $\mathrm{Cr}$ concentrations in the studied medicinal plant were observed higher while Zn concentration was observed lower than (Jabeen et al. 2010), in important therapeutic plants of Haripur basin northern Pakistan. Moreover, $\mathrm{Cd}, \mathrm{Ni}, \mathrm{Pb}$ and $\mathrm{Zn}$ concentration were found higher whereas $\mathrm{Mn}$ and $\mathrm{Cr}$ were found lower than (Muhammad et al. 2011). Agreeing to the world health organization (WHO, 1998) around $80 \%$ of the global residents use plant-based medications. Majority of these plants are collected in the wild, only few might be cultivated. Some of the important mineral elements bio-accumulate in these medicinal plants. Other trace elements such as $\mathrm{Cr}, \mathrm{Pb}$ and $\mathrm{Cd}$, which are not useful for plants and are detrimental to human health, also accumulate in these plants (Bakers and Brooks, 1989; Lasisi et al. 2005). The ecological impact of these PTEs as well as their health effects has been a source of major concern. Their accumulation in plants highly depends on the availability in the soil (Khan et al., 2007). Potentially toxic elements contamination of medicinal herbal products occurs during cultivation, cross-contamination during processing or their deliberate introduction as therapeutic ingredients. Cultivation in soils containing high concentrations of toxic metals is one mechanism by which PTEs contamination of herbal products has been documented (Quig, 1998) Medicinal plants are widely consumed by both developing and developed nations due to their low price, safety and low side effects, but unfortunately, limited efforts have been taken for the assessment of PTEs accumulation in these plants and there are no international standards available for their safety regarding PTEs. Hence, there is a need for the best monitoring body on an international level for the assessment of PTEs in medicinal plants.

Several studies have reported the presence of PTEs in plants from different regions of the world as summarized in (Table 6). The present study show the concentration of PTEs in medicinal plants in Pakistan i.e. Zn: $5.5-38.40 \mathrm{mg} \mathrm{kg}^{-1}$, Mn: 20-304 mg kg-1, Pb: 4-335 mg kg${ }^{-1}$, Ni: $24-169 \mathrm{mg} \mathrm{kg}^{-1}$, Cd: 1-11 $\mathrm{mg} \mathrm{kg}^{-1}$ and $\mathrm{Cr}: 39-349 \mathrm{mg} \mathrm{kg}^{-1}$, respectively. Another study in Pakistan showed the level of PTEs in herbal medicine for $\mathrm{Zn}: 83.7-433.7 \mathrm{mg} \mathrm{kg}{ }^{-1}, \mathrm{~Pb}: 3.26-30.4 \mathrm{mg} \mathrm{kg}^{-1}$, Ni: $0.48-76.9 \mathrm{mg} \mathrm{kg}^{-1}, \mathrm{Cd}$ : 1.6-4.91 $\mathrm{mg} \mathrm{kg}^{-1}$ and $\mathrm{Cr}: 1.6-186.7 \mathrm{mg} \mathrm{kg}^{-1}$ (Hina et al. 2011). Likewise, in Brazil, one hundred and thirty samples of medicinal plants were analyzed for $\mathrm{Cd}, \mathrm{Hg}$ and $\mathrm{Pb}$. The investigated concentration for 
Cd was $0.22-0.74 \mathrm{mg} \mathrm{kg}^{-1}$ and $\mathrm{Pb} 2-11.7 \mathrm{mg} \mathrm{kg}^{-1}$ (Caldasa and Machado 2004). Similarly, in China 334 samples representing 126 commonly prescribed Chinese medicinal plant species were examined for $\mathrm{Ar}, \mathrm{Cd}, \mathrm{Cr}, \mathrm{Pb}$, and $\mathrm{Hg}$. The reported concentration was $0.02-4.35 \mathrm{mg} \mathrm{kg}^{-1}$ for $\mathrm{Cd}, 0.01-21 \mathrm{mg} \mathrm{kg}^{-1}$ for $\mathrm{Cr}$ and $0.04-8.15 \mathrm{mg} \mathrm{kg}^{-1}$ for $\mathrm{Pb}$ (Harris et al. 2011). In Egypt, PTEs were investigated in 835 samples of leafy vegetables and some aromatic medicinal plants. The study showed the value of $0.004-0.13 \mathrm{mg}$ $\mathrm{kg}^{-1}$ for $\mathrm{Cd}$ and $0.06-5.9 \mathrm{mg} \mathrm{kg}^{-1}$ for Pb (Dogheim et al. 2004). In the USA PTEs were determined in forty-seven samples of ginseng extracts bought from 20 suppliers in China, Europe, and the USA. The reported concentration for $\mathrm{Cd}$ was $0.05-259 \mathrm{mg} \mathrm{kg}^{-1}$ and $\mathrm{Pb}$ was $3-2710 \mathrm{mg} \mathrm{kg}^{-1}$ (Durgnat et al. 2005). In Ethiopia 26 samples of 8 different plant species were gathered from four different places and were investigated for the accumulation of $\mathrm{Pb}$ and $\mathrm{Cd}$, the studies revealed that the amount of $\mathrm{Pb}$ was $0.17-$ $98.2 \mathrm{mg} \mathrm{kg}^{-1}$ and Cd was $0.17-1.8 \mathrm{mg} \mathrm{kg}^{-1}$ (Baye and Hymete 2010). In South Africa eight medicinal plants purchased from street markets were evaluated for PTEs, the reported amount for $\mathrm{Cd}$ was up to $0.02 \mathrm{mg} \mathrm{kg}^{-1}$ and $\mathrm{Pb}$ was up to $4.7 \mathrm{mg} \mathrm{kg}^{-1}$ (Street et al. 2008). In Botswana twelve traditionally used medicinal plant species were supplied from Ngami-land district for determination of potentially toxic metals. The results showed that $\mathrm{Cr}$ and $\mathrm{Pb}$ were present in all plant samples while nickel was detected in only 3 plant species. The concentration present in medicinal plants for $\mathrm{Cr}$ ranged from $0.15-1.27 \mathrm{mg} \mathrm{kg}^{-}$ ${ }^{1}$, $\mathrm{Pb} 0.12-0.23 \mathrm{mg} \mathrm{kg}^{-1}$ and Ni $0.09-0.21 \mathrm{mg} \mathrm{kg}^{-1}$ (Okatch et al. 2012). In Sudan thirty-three popular medicinal plants collected from the local market were tested for PTEs, the detected concentration for $\mathrm{Cd}$ was $0.8-187 \mathrm{mg} \mathrm{kg}^{-1}$ and $\mathrm{Pb}$ was $2.6-481 \mathrm{mg} \mathrm{kg}^{-1}$ (Ebrahim et al. 2012). In India PTEs in medicinal plants gathered from environmentally diverse sites were quantitatively analyzed, the reported results for Cr was $0.24-1.4 \mathrm{mg} \mathrm{kg}^{-1}, \mathrm{Cd}: 0.18-0.5$ and $\mathrm{Pb} 0.24-0.51 \mathrm{mg} \mathrm{kg}^{-1}$ (Sadhu et al. 2015) as shown in (Table 8). Hence, the given data shows that medicinal plant in degraded mining areas in Pakistan are highly contaminated in terms of PTEs as compared to other parts of the world.

\section{$\mathrm{Cd}$ and $\mathrm{Pb}$ concentration and risk to public health}

The level of $\mathrm{Cd}$ and $\mathrm{Pb}$ in the medicinal plant species ranged from 1 to $11 \mathrm{mg} \mathrm{kg}^{-1}$ and 4 to $335 \mathrm{mg} \mathrm{kg}^{-1}$. The standards set by WHO (2007) for Cd and Pb in medicinal herbs are $0.3 \mathrm{mg} \mathrm{kg}^{-1}$ and $\mathrm{Pb} 10 \mathrm{mg} \mathrm{kg}^{-}$

1 respectively, which indicate that most of the plant species exceeded these limits and showing high concentrations for the analyzed elements. Another study in Pakistan showed the level of Cd: $1.08 \mathrm{mg} \mathrm{kg}^{-}$ 1 and $\mathrm{Pb}: 18.98 \mathrm{mg} \mathrm{kg}^{-1}$ (Hina et al. 2011). A high concentration of $\mathrm{Cd}$ can cause phyto-toxicity such as chlorosis of leaf, germination inhibition and plant biomass reduction (Nawab et al. 2015a). Furthermore, Cd has a long biological life after accumulation in the body, which exerts toxic effects on lungs, kidneys, bone, liver, immune and cardiovascular system (Dai et al., 2011). Pb is also one of those elements which cause a major health concern including DNA damage, affect reproductive systems, cardiovascular system, nervous system as well as kidney and liver (Mutlu et al. 2021). From this result, it is concluded that most of the medicinal plant species have high levels of $\mathrm{Pb}$ and $\mathrm{Cd}$. Therefore, for the quality and safety of medicinal plants, it is essential to assess the level of toxic elements. The present study revealed that $\mathrm{Cd}$ and $\mathrm{Pb}$ concentration in selected medicinal plants may exert a potential health risk to the local 
community of the study area as most of the inhabitants use these plants for various types of health remedies.

\section{Statistical analysis of degraded mining soils and medicinal plant species}

In order to detect the significant differences of PTE concentrations in the study area and reference site, one-way ANOVA (analysis of variance) was performed. One-way ANOVA allowed simultaneous testing the significant difference of the mean. For this test, both reference and contaminated sampling locations were selected as a group and its PTE concentrations as the corresponding variables. The difference statistical significance was determined at the $95 \%$ confidence level and reported as $P>0.05$ (nonsignificant) and $\mathrm{P}<0.01$ (significant) levels. Tables 7 and 8 show the one-way ANOVA of degraded mining soils and medicinal plant species, respectively. One-way ANOVA result revealed that the study area has a significantly $(p<0.001)$ higher level of PTEs concentration as compared to the reference site. This multi-fold higher concentration of PTEs is due to the presence of mafic and ultra-mafic rocks and chromite mining in the area (Nawab et al., 2015a). Inter-elemental correlation (Table 9) provides information about elemental sources and pathways. Inter-elemental correlation of soil samples shows that some pairs in soil have positive correlations such as EC-Zn (0.478), SOM-Zn (0.398), Pb-Ni (0.453) EC-Cd (0.433) and EC-Cr (0.401), while in plants there is no positive correlation observed. These interelemental correlation metrics proved that these relationships were not strongly significant in soil and plants which may be attributed to the physiologies of plant species and different physicochemical properties of the soil (Muhammad et al. 2013).

\section{Conclusion}

In this study, concentrations of PTEs ( $\mathrm{Pb}, \mathrm{Cd}, \mathrm{Cr}, \mathrm{Zn}, \mathrm{Mn}$ and $\mathrm{Ni}$ ) were analyzed in soils and medicinal plants. Results demonstrated that the highest value of $\mathrm{Pb}\left(335 \mathrm{mg} \mathrm{kg}^{-1}\right)$ was found in Phlomis bracteosa followed by $\mathrm{Cr}\left(349 \mathrm{mg} \mathrm{kg}^{-1}\right)$ in Ajuga bracteosa, $\mathrm{Mn}\left(304.3 \mathrm{mg} \mathrm{kg}^{-1}\right)$ in Chenopodium ambrosioides, $\mathrm{Ni}\left(158 \mathrm{mg} \mathrm{kg}^{-1}\right)$ in Phlomis bracteosa, Zn (38.4 $\mathrm{mg} \mathrm{kg}^{-1}$ ) in Ajuga parviflora and Cd (11 $\mathrm{mg} \mathrm{kg}^{-1}$ ) in Salvia moorcoftiana. The highest $\mathrm{CF}$ value was found in the soil for $\mathrm{Ni}(15.51)$ and in plants for $\mathrm{Cr}$ (11.37). The PLI value (7.81) in soil indicated that the area has been extremely polluted from the anthropogenic activities. These high concentrations of PTEs, PLI and CF values may be attributed to the presence of mafic-ultramafic rocks, weathering and erosion of these rocks and open dumping of mining wastes. The results of this study revealed that selected soils and medicinal plant species were consistently contained an extensive amounts of toxic elements, therefore, it is recommended that efficient measures should be taken to reduce the amounts of PTEs in the study area to protect human health and the surrounding environment.

\section{Declarations}

\section{Acknowledgments}


The research work was supported by Hainan Provincial Natural Science Foundation of China (319MS008), National Nature Science Foundation of China (41571288), Research initiation fund of Hainan University (KYQD (ZR) 20032) and Pakistan Science Foundation under National Sciences Linkages Program Project No. (PSF/NSLP/KP-AWKUM (827)

\section{Ethics approval and consent to participate}

Not Applicable

\section{Consent for publication}

Not Applicable

\section{Competing interests}

The authors declare that they have no competing interests

\section{Author's contributions}

The first (Syed Wasim Sardar) and corresponding author (Dr. Javed Nawab) were the major contributors in developing the idea and writing of this paper. While Dr. Sardar, Dr. Abid, Dr. Zia, Dr. Aziz and Dr. M. Qayash help in lab, polishing, editing and preparing tables for this paper.

\section{Funding}

The financial support was provided by Pakistan Science Foundation under project no. (PSF/NSLP 827 (AWKUM).

\section{Availability of data and materials}

Not Applicable

Conflict of interest: The authors declare that they have no conflict of interest.

\section{References}

Ahmed E, Arshad M, Saboor A, Qurehi R, Mustafa G, Sdiq S, Chaudhari S K (2013) Ethnobotanical Appraisal and Medicinal Use of Plants in Patriata, New Murree, Evidence from Pakistan. J Ethnobiology and Ethnomedicine 13:1-10

Ali S I, Qaiser M (1986) A Phytogeographical Analysis of the Phanerogams of Pakistan and Kashmir. Proc. R. Soc. Edinburg 89B:89-101

Baker AJM, Brooks RR. Terrestrial higher plants, which hyperaccumulate metallic elements-A review of their distribution, ecology and phytochemistry. Biorecovery. 1989;1:81-126. 
Baye $\mathrm{H}$, Hymete A (2010) Lead and cadmium accumulation in medicinal plants collected from environmentally different sites. Bull. Environ. Contam.Toxicol 84: 197-201

Caldasa E D, Machado L L (2004) Cadmium, mercury and lead in medicinal herbs in Brazil. Food Chem. Toxicol 42: 599-603

Dogheim S M, Ashraf El M M et al (2004) Pesticides and Heavy Metals Levels in Egyptian Leafy Vegetables and Some Aromatic Medicinal Plants. Food Additives and Contaminants 21(4): 323-30

Durgnat J M, Heuser J, Andrey, D, Perrin C (2005) Quality andsafety assessment of ginseng extracts by determination of the contents of pesticides and metals. Food Addit.Contam 22 (12): 1224-1230

Ebrahim A.M, Eltayeb M.H, Khalid H, Mohamed H, Abdalla W, Grill P, Michalke B, (2012) Study on selected trace elements and heavy metals in some popular medicinal plants from Sudan. J. Nat. Med. 66 (4): $671-679$

Fatima I, Anis I, Ahmad I et al (2007) A New Alkaloid from Isatis Costata. Turkish Journal of Chemistry 31(4): 443-47

Ghiasuddin, Rehman T U et al (2011) Antimicrobial, Insecticidal and Phytotoxic Activities of Indigofera Heterantha Roots. Journal of Medicinal Plant Research 5(24): 5835-39

Hazrat A, Shah J et al (2010) Medicinal Plants of Usherai Valley, Dir, NWFP, Pakistan. Pakistan Journal of Botany 42(1): 31-34

Harris E S, Cao S, Littlefield B A, Craycroft J A, Scholten R, Kaptchuk T, Yanling Fu et al (2011). Heavy metal and pesticide content in commonly prescribed individual raw Chinese herbal medicines. Sci. Total Environ. 409: 4297-4305

Hina B, Rizwani, G H, Naseem S (2011) Determination of toxic metals in some herbal drugs through atomic absorption spectroscopy. Pak. J. Pharm. Sci. 24: 353-358

Jabeen S, Shah M T, Khan S, Hayat M Q (2010) Determination of Major and Trace Elements in Ten Important Folk Therapeutic Plants of Haripur Basin, Pakistanx. Journal of Medicinal Plants Research 4(7): 559-66

Khan A, Khan S, Khan M A, Qamar Z, Waqas M (2015) The Uptake and Bioaccumulation of Heavy Metals by Food Plants, Their Effects on Plants Nutrients, and Associated Health Risk: A Review. Environmental Science and Pollution Research 22(18): 13772-99

Khan MA, Ahmad I, Rahman I. Effect of environmental pollution on heavy metals content of Withania somnifera. Journal of the Chinese Chemical Society. 2007; 54:339-43 
Khan, S A, Khan L et al (2008) Profile of Heavy Metals in Selected Medicinal Plants. J. Weed Sci. Res 14(12): 101-10

Kumar M, Paul Y, Anand V K (2009) An Ethnobotanical Study of Medicinal Plants Used by the Locals in Kishtwar , Jammu and Kashmir , India. Journal of Ethnobiology and Ethnomedicine 13(1956): 1240-56

Lajayer A, Behnam, Ghorbanpour M, Nikabadi S (2017) Heavy Metals in Contaminated Environment: Destiny of Secondary Metabolite Biosynthesis, Oxidative Status and Phytoextraction in Medicinal Plants. Ecotoxicology and Environmental Safety 145: 377-90

Lasisi AA, Yusuff AA, Ejelonu BC, Nwosu EO, Olayiwola MA. Heavy metals and macronutrients content in selected herbal plants of Nigeria. International Jour Chern. 2005;15:147-54

Alam M, Ghiasuddin et al (2012) Evaluation of Viburnum Grandiflorum for Its In-Vitro Pharmacological Screening. African Journal of Pharmacy and Pharmacology 6(22): 1606-1610

Muhammad S, Shah M T, Khan S et al (2013) Wild Plant Assessment for Heavy Metal Phytoremediation Potential along the Mafic and Ultramafic Terrain in Northern Pakistan. BioMed Research International 2013 (194765)

Muhammad S, Shah M T, Khan S (2011) Heavy Metal Concentrations in Soil and Wild Plants Growing around Pb-Zn Sulfide Terrain in the Kohistan Region, Northern Pakistan. Microchemical Journal 99(1): $67-75$

Muller G. 1969. Index of geo-accumulation in sediments of the Rhine 680 River. Geology Journal 2:108118.

Mutlu S I, Seven I, Arkali G et al (2021) Ellagic Acid Plays an Important Role in Enhancing Productive Performance and Alleviating Oxidative Stress, Apoptosis in Laying Quail Exposed to Lead Toxicity. Ecotoxicology and Environmental Safety 208: 111608

Nawab J, Khan S, Shah M T, Qamar Z, et al (2015a) Contamination of Soil, Medicinal, and Fodder Plants with Lead and Cadmium Present in Mine-Affected Areas, Northern Pakistan. Environmental Monitoring and Assessment 187(9)

Nawab J, Khan S, Shah M T, Khan K et al (2015b) Quantification of Heavy Metals in Mining Affected Soil and Their Bioaccumulation in Native Plant Species. International Journal of Phytoremediation 17(9): 801-13.

Nawab J, Khan S, Shah M T, Gul N, Ali A, Khan K, \& Huang, Q. (2016a). Heavy metal bioaccumulation in native plants in chromite impacted sites: a search for effective remediating plant species. CLEAN-Soil, Air, Water, 44(1), 37-46. 
Nawab, J., Li, G., Khan, S., Sher, H., et al (2016b). Health risk assessment from contaminated foodstuffs: a field study in chromite mining-affected areas northern Pakistan. Environmental Science and Pollution Research, 23(12), 12227-12236.

Okatch H, Ngwenya B, Raletamo K M, Marobela K A (2012) Determination of Potentially Toxic Heavy Metals in Traditionally Used Medicinal Plants for HIV/AIDS Opportunistic Infections in Ngamiland District in Northern Botswana. Analytica Chimica Acta 730: 42-48

Okello J, and Paul S (2007) Medicinal Plants Used by Communities of Ngai Subcounty, Apac District, Northern Ugand. African Journal of Ecology 45(1): 76-83

Okem A, Southway C, Stirka W A, Street R A, Finniea J F, Staden J V (2014) Heavy Metal Contamination in South African Medicinal Plants: A Cause for Concern. South African Journal of Botany 93: 125-30

Quig D. Cysteine metabolism and metal toxicity. Altern Med Rev. 1998;3:262-70.

Rana, J C, Pradheep K, Chaurasia O P et al (2012) Genetic Resources of Wild Edible Plants and Their Uses among Tribal Communities of Cold Arid Region of India. Genetic Resources and Crop Evolution 59(1): 135-49

Rehman A, Iqbal H, Rehman H U, et al (2013) Study of Heavy Metals in Medicinal Plant Solanum Xanthocarpum. International Journal of Science Innovations and Discoveries 3(2):254-260

Sadhu A, Upadhyay P, Singh PK, et al (2015) Quantitative Analysis of Heavy Metals in Medicinal Plants Collected from Environmentally Diverse Locations in India for Use in a Novel Phytopharmaceutical Product. Environ Monit Assess 187, 542

Sarac N, Ugur A (2007) Antimicrobial Activities and Usage in Folkloric Medicine of Some Lamiaceae Species Growing in Mugla, Turkey. EurAsian Journal of BioSciences 4: 28-37

Sekar C K, Rawat B (2011) Diversity, Utilization and Conservation of Ethnomedicinal Plants in Devikund A High Altitude, Sacred Wetland of Indian Himalaya. Medicinal Plants 3(2): 105-12

Shabana M M, Mirhom Y W, Genenah AA, Aboutabl E A, Amer H A (1990) Study into wild Egyptian plants of potential medicinal activity. Arch Exp Veterinarmed 44: 389-394

Shah G M Jamal Z AND Hussain M (2013) Phytotheraphy among the rural women of district Abottabad Pak. J. Bot., 45(SI): 253-261

Sharma R A, Singh B, Singh D, Chandrawat P (2009) Ethnomedicinal, Pharmacological Properties and Chemistry of Some Medicinal Plants of Boraginaceae in India. Journal of Medicinal Plants Research 3(13): 1153-75 
Shen Z J, Xu D C, Chen Y S, Zhang Z (2017) Heavy Metals Translocation and Accumulation from the Rhizosphere Soils to the Edible Parts of the Medicinal Plant Fengdan (Paeonia Ostii) Grown on a Metal Mining Area, China. Ecotoxicology and Environmental Safety 143: 19-27

Shinwari Z K, Gilani S S (2003) Sustainable Harvest of Medicinal Plants at Bulashbar Nullah, Astore (Northern Pakistan). Journal of Ethnopharmacology 84(2-3): 289-98

Shinwari, Z K, Qaiser M (2011) Efforts on Conservation and Sustainable Use of Medicinal Plants of Pakistan. Pakistan Journal of Botany 43: 5-10

Street R, Kulkarni, M G, Stirk, W.A, Southway, C, Van Staden, J (2008) Variation in heavy metals and microelements in South African medicinal plants obtained from street markets. Food Addit.Contam. Part A 25 (8): 953-960

Ullah R, Hussain I S, Ahmad S (2013) Phytochemical and Biological Evaluation of Phlomis Bracteosa: A Review. Life Science Journal 10(7): 1190-92

Wang J, Su J, Li Z, Liu B et al (2019) Source Apportionment of Heavy Metal and Their Health Risks in Soil-Dustfall-Plant System Nearby a Typical Non-Ferrous Metal Mining Area of Tongling, Eastern China. Environmental Pollution 254: 113089

WHO. WHO: Geneva Switzerland; 1998. Quality control methods for medicinal plant materials. available at http://whqlibdoc.who.int/publications/1998/9241545100.pdf

Wu L Y, Gao H Z, Wang X L et al (2010) Analysis of Chemical Composition of Chrysanthemum Indicum Flowers by GC/MS and HPLC. Journal of Medicinal Plants Research 4(5): 421-26

Zeng, Jian, Li X, Wang X et al (2020) Cadmium and Lead Mixtures Are Less Toxic to the Chinese Medicinal Plant Ligusticum Chuanxiong Hort. Than Either Metal Alone. Ecotoxicology and Environmental Safety 193: 110342

Zhao X, Liu J, Xia X et al (2014) The Evaluation of Heavy Metal Accumulation and Application of a Comprehensive Bio-Concentration Index for Woody Species on Contaminated Sites in Hunan, China. Environmental Science and Pollution Research 21(7): 5076-85

\section{Tables}

Table 1. Physicochemical parameters of soil from reference and contaminated site 


\begin{tabular}{llll}
\hline Properties & Statistics & Reference & Contaminated \\
\hline pH & Range & $5.5-7$ & $7.3-7.8$ \\
& Mean & 6.3 & 7.64 \\
\cline { 2 - 4 } & RSD & 0.7 & 0.14 \\
EC $^{*}$ s cm $^{-1}$ & Range & $0.1-1.3$ & $208-252$ \\
\cline { 2 - 4 } & Mean & 0.5 & 225.11 \\
\cline { 2 - 4 } & RSD & 0.5 & 16.592 \\
\hline \multirow{2}{*}{ SOM $^{*} \%$} & Range & $1.8-2.5$ & $1.5-1.78$ \\
& Mean & 2.1 & 1.68 \\
& RSD & 0.3 & 0.0666 \\
\hline
\end{tabular}

${ }^{*}$ EC: Electric conductivity

*SOM: Soil organic matter

Table 2. Concentration range, contamination Factor (CF) and pollution load index (PLI) of PTEs from the soil of the study area

\begin{tabular}{llllllll}
\hline \multicolumn{7}{l}{ Reference site } & \multicolumn{7}{l}{ Contaminated site } \\
\hline PTEs & Range & Mean & ${ }^{*}$ SD & Range & Mean & SD & CF \\
Zn & $12.00-23.42$ & 15.32 & 7.05 & $9.5-261.60$ & 52.77 & 47.67 & 3.44 \\
$\mathrm{Mn}$ & $14.25-25.54$ & 80.89 & 105.8 & $387.30-956.0$ & 562.64 & 139.37 & 1.71 \\
$\mathrm{~Pb}$ & $15.51-18.68$ & 17.56 & 1.78 & $16.0-633.2$ & 157.36 & 135.957 & 8.96 \\
$\mathrm{Ni}$ & $12.65-28.98$ & 34.71 & 25.42 & $200.00-1008.0$ & 538.57 & 194.44 & 15.51 \\
$\mathrm{Cd}$ & $0.08-0.14$ & 0.32 & 0.36 & $1.0-16.0$ & 5.96 & 3.52 & 18.26 \\
$\mathrm{Cr}$ & $13.08-20.45$ & 37.24 & 35.6 & $90.0-1751.0$ & 566.96 & 435.187 & 15.22 \\
$\mathrm{PLI}$ & & & & & & & 7.81 \\
\hline
\end{tabular}

*SD: Standard deviation

Table 3. Contamination Factor (CF) of PTEs in plant species of reference and contaminated site 


\begin{tabular}{llllllll}
\hline \multicolumn{2}{l}{ Reference site } & & \multicolumn{5}{l}{ Contaminated site } \\
\hline PTEs & Range & Mean & SD & Range & Mean & SD & CF \\
Zn & $10.30-18.2$ & 15.76 & 4.7 & $5.50-38.40$ & 15.08 & 7.40 & 0.95 \\
Mn & $5.20-15.32$ & 9.69 & 5.1 & $20.0-304.3$ & 94.68 & 69.29 & 9.7 \\
$\mathrm{~Pb}$ & $14.5-30.53$ & 21.43 & 8.2 & $4.0-335.0$ & 104.3 & 90.7 & 4.8 \\
$\mathrm{Ni}$ & $4.06-19.45$ & 14.18 & 8.7 & $24-169$ & 76.85 & 39.85 & 5.41 \\
$\mathrm{Cd}$ & $0.10-0.89$ & 0.46 & 0.39 & $1-11$ & 4.64 & 2.72 & 10.08 \\
$\mathrm{Cr}$ & $6.5-18.87$ & 12.56 & 6.1 & $17.0-349.0$ & 131.14 & 97.0 & 11.37 \\
\end{tabular}

*SD: Standard deviation 
Table 4. Selected medicinal plants from Indus Kohistan region northern, Pakistan

\begin{tabular}{|c|c|c|c|c|c|}
\hline Botanical name & Family name & Local name & Parts use & Medicinal uses & References \\
\hline Artemisia vulgaris & Asteraceae & Tarkha & $\begin{array}{l}\text { Aerial } \\
\text { Part }\end{array}$ & Anthelmintic & $\begin{array}{l}\text { Ahmed et } \\
\text { al. } 2013\end{array}$ \\
\hline $\begin{array}{l}\text { Chrysanthemum } \\
\text { indicum }\end{array}$ & Asteraceae & - & $\begin{array}{l}\text { Whole } \\
\text { plant }\end{array}$ & $\begin{array}{l}\text { Used for eye diseases in } \\
\text { china, analgesic, Anti- } \\
\text { inflammatory, antipyretic } \\
\text { purposes }\end{array}$ & $\begin{array}{l}\text { Wu et al. } \\
2010\end{array}$ \\
\hline Plantago lanceolata & Plantaginaceae & Jabey & $\begin{array}{l}\text { Leaves, } \\
\text { Fruit }\end{array}$ & Dysentery, Laxative & $\begin{array}{l}\text { Ahmad et } \\
\text { al. } 2013\end{array}$ \\
\hline Cirsium arvense & Asteraceae & Kandehiara & $\begin{array}{l}\text { Leaves, } \\
\text { Root }\end{array}$ & Vomiting & $\begin{array}{l}\text { Kumar et } \\
\text { al. } 2009\end{array}$ \\
\hline $\begin{array}{l}\text { Cynoglossum } \\
\text { lanceolatum }\end{array}$ & Boraginaceae & $\begin{array}{l}\text { Choro/ Gat } \\
\text { gul }\end{array}$ & $\begin{array}{l}\text { whole } \\
\text { plant }\end{array}$ & $\begin{array}{l}\text { Nephritic oedema, acute } \\
\text { nephritis, and toothache }\end{array}$ & $\begin{array}{l}\text { Sharma et } \\
\text { al. } 2009\end{array}$ \\
\hline Isodon rugosus & Lamiaceae & $\begin{array}{l}\text { Phaypush } \\
\text { /Burtus }\end{array}$ & Leaves & Antiseptic & $\begin{array}{l}\text { Ahmad et } \\
\text { al. } 2013\end{array}$ \\
\hline Verbascum thapsus & Scrophulariaceae & Kharghwag & $\begin{array}{l}\text { Whole } \\
\text { plant }\end{array}$ & $\begin{array}{l}\text { Narcotic, antiseptic, } \\
\text { diarrhea also dysentery } \\
\text { of cattle, cough, and } \\
\text { pulmonary diseases }\end{array}$ & $\begin{array}{l}\text { Ahmad et } \\
\text { al. } 2013\end{array}$ \\
\hline Rumex hastatus & Polygonaceae & Tharukay & $\begin{array}{l}\text { Leaves } \\
\text { and young } \\
\text { shoots }\end{array}$ & $\begin{array}{l}\text { Stomach diseases, } \\
\text { astringent, purgative, } \\
\text { diuretic, carminative }\end{array}$ & $\begin{array}{l}\text { Ahmad et } \\
\text { al. } 2013\end{array}$ \\
\hline Sonchus arvensis & Asteraceae & $\begin{array}{l}\text { Dodak/ } \\
\text { Doddal }\end{array}$ & $\begin{array}{l}\text { whole } \\
\text { plant }\end{array}$ & $\begin{array}{l}\text { treat bronchial disorders } \\
\text { dissolving kidney stones }\end{array}$ & $\begin{array}{l}\text { Shah et al. } \\
2015\end{array}$ \\
\hline Phlomis bracteosa & Lamiaceae & - & $\begin{array}{l}\text { whole } \\
\text { plant }\end{array}$ & $\begin{array}{l}\text { Bone fractures, sinus } \\
\text { congestion, lymph fluid } \\
\text { disorder and indigestion }\end{array}$ & $\begin{array}{l}\text { Ullah et al. } \\
2013\end{array}$ \\
\hline Ajuga bracteosa & Lamiaceae & Booti & $\begin{array}{l}\text { Whole } \\
\text { plant }\end{array}$ & $\begin{array}{l}\text { Respiratory diseases, } \\
\text { jaundice, hypertension }\end{array}$ & $\begin{array}{l}\text { Ahmad et } \\
\text { al. } 2013\end{array}$ \\
\hline Diospyros lotus & Ebenaceae & $\begin{array}{l}\text { Toor } \\
\text { amlook }\end{array}$ & Fruit & purgative, carminative & $\begin{array}{l}\text { Ahmad et } \\
\text { al. } 2013\end{array}$ \\
\hline Euphorbia peplus & Euphorbiaceae & Dudh booti & Whole & $\begin{array}{l}\text { Liver ailments, asthma, } \\
\text { and joint pains. }\end{array}$ & $\begin{array}{l}\text { Shah et al. } \\
2015\end{array}$ \\
\hline Indigofera heterantha & Fabaceae. & Ghoreja & $\begin{array}{l}\text { Leaves } \\
\text { and roots }\end{array}$ & $\begin{array}{l}\text { Used for the treatment } \\
\text { of abdominal pain, and } \\
\text { various skin infections } \\
\text { and other infectious } \\
\text { disease }\end{array}$ & $\begin{array}{l}\text { Ghiasuddin } \\
\text { et al. } 2011\end{array}$ \\
\hline Galium asperuloides & Rubiaceae & Gaya & $\begin{array}{l}\text { Whole } \\
\text { plant }\end{array}$ & $\begin{array}{l}\text { Plant paste used on skin } \\
\text { burning }\end{array}$ & $\begin{array}{l}\text { Sekar et } \\
\text { al. } 2011\end{array}$ \\
\hline Cerastium fontanum & Caryophyllaceae & - & $\begin{array}{l}\text { Whole } \\
\text { plant }\end{array}$ & Used in fever, coughs & $\begin{array}{l}\text { Rana et al. } \\
2012\end{array}$ \\
\hline Conyza sp & Asteraceae & - & Root & $\begin{array}{l}\text { Respiratory disorders, } \\
\text { Epilepsy, HIV/AIDS- } \\
\text { related abdominal pains }\end{array}$ & $\begin{array}{l}\text { Okello \& } \\
\text { Ssegawa } \\
2007\end{array}$ \\
\hline Limoniom cabulicum. & plumbaginaceae & ghwakhakai & $\begin{array}{l}\text { Whole } \\
\text { plant }\end{array}$ & $\begin{array}{l}\text { Used for the treatment } \\
\text { of several diseases } \\
\text { including diabetes }\end{array}$ & $\begin{array}{l}\text { Shabana et } \\
\text { al. } 1990\end{array}$ \\
\hline Stachys emodi & Lamiaceae & Dagcayi & Leaf & $\begin{array}{l}\text { Used for the relief of } \\
\text { abdominal pain, gastric }\end{array}$ & $\begin{array}{l}\text { Sarac \& } \\
\text { Ugur } 2007\end{array}$ \\
\hline
\end{tabular}


pain, stomach disease,

and for the treatment of

malaria

Isatis costata.

Brassicaceae

Zangali

Roots and

Used as anti-

Fatima et

Moli

leaves

inflammatory, antiviral,

antipyretic, and

detoxifying Purposes

Table 5. PTEs concentrations and translocation $\left(\mathrm{mg} \mathrm{kg}^{-1}\right)$ factor in medicinal plant species.

\begin{tabular}{|c|c|c|c|c|c|c|c|c|c|c|c|c|c|}
\hline No & Medicinal Plants Name & $\mathrm{Zn}$ & $\mathrm{TF}^{*}$ & $\mathrm{Mn}$ & $\mathrm{TF}$ & $\mathrm{Pb}$ & $\mathrm{TF}$ & $\mathrm{Ni}$ & $\mathrm{TF}$ & $\mathrm{Cd}$ & $\mathrm{TF}$ & $\mathrm{Cr}$ & $\mathrm{TF}$ \\
\hline 1 & Artemisia vulgaris & 12.2 & 0.82 & 160 & 0.32 & 50 & 0.20 & 88 & 0.17 & 3 & 0.37 & 171 & 0.56 \\
\hline 2 & Chrysanthemum indicum & 29.6 & 0.82 & 174 & 0.31 & 107 & 1.18 & 47 & 0.06 & 5 & 0.71 & 215 & 0.23 \\
\hline 3 & Plantago lanceolata & 13.5 & 1.42 & 20 & 0.033 & 94 & 1.13 & 133 & 0.19 & 2 & 0.4 & 90 & 0.32 \\
\hline 4 & Cirsium arvense & 11 & 0.31 & 77 & 0.13 & 206 & 3.88 & 107 & 0.13 & 3 & 0.5 & 77 & 0.85 \\
\hline 5 & $\begin{array}{l}\text { Cynoglossum } \\
\text { lanceolatum }\end{array}$ & 14.2 & 1.22 & 64.2 & 0.13 & 29 & 0.26 & 80 & 0.13 & 7 & 1.75 & 17 & 0.07 \\
\hline 6 & Isodon rugosus & 13.5 & 0.91 & 181.5 & 0.34 & 45 & 0.64 & 30 & 0.05 & 6 & 1.2 & 78 & 0.19 \\
\hline 7 & Verbascum Thapsus & 23.7 & 0.31 & 73.7 & 0.15 & 107 & 0.44 & 24 & 0.03 & 1 & 1 & 120 & 0.24 \\
\hline 8 & Rumex hastatus & 13 & 0.23 & 71.9 & 0.19 & 217 & 13.56 & 90 & 0.12 & 8 & 1.14 & 69 & 0.29 \\
\hline 9 & Sonchus arvensis & 13.6 & 0.69 & 114.3 & 0.14 & 43 & 0.67 & 80 & 0.11 & 7 & 7 & 98 & 0.16 \\
\hline 10 & Phlor & 2.1 & 1.79 & 50 & 0.079 & 335 & 10.15 & 158 & 0.28 & 8 & 2 & 55 & 0.18 \\
\hline 11 & Erigeron Canadensis & 19.7 & 0.37 & 113.3 & 0.17 & 135 & 1.43 & 35 & 0.06 & 9 & 3 & 60 & 0.49 \\
\hline 12 & Ajuga bracteosa & 1.1 & 0.25 & 23.4 & 0.0 & 275 & 0.43 & 122 & 0.30 & 3 & 0.3 & 349 & 0.51 \\
\hline 13 & Diosp & 7.6 & 0.16 & 111.3 & 0.21 & 197 & 1.36 & 39 & 0.06 & 6 & 3 & 57 & 0.23 \\
\hline 14 & Euph & 13.9 & 0.91 & 29.4 & & 217 & 1.27 & 84 & 0.13 & 8 & 1.6 & 80 & 0.087 \\
\hline 15 & Indigofera heterantha & 8.1 & 0.24 & 105.7 & 0.11 & 62 & 2.58 & 31 & 0.03 & 1 & 0.11 & 60 & 0.11 \\
\hline 16 & Galiumas peruloides & 11 & 0.18 & 42.3 & 0.0 & 238 & 6.61 & 40 & 0.05 & 3 & 0.5 & 323 & 0.33 \\
\hline 17 & ium fontanum & 6.8 & 0.11 & 41 & 0.088 & 38 & 1.18 & 118 & 0.21 & 2 & 0.66 & 60 & 0.32 \\
\hline 18 & Conyzá & 20.2 & 0.35 & 117 & 0.24 & 41 & 0.25 & 64 & 0.09 & 7 & 7 & 126 & 0.56 \\
\hline 19 & Limoniom cabulicum & 22.4 & 0.40 & 48.4 & 0.08 & 5 & 0.03 & 65 & 0.32 & 1 & 0.09 & 285 & 0.70 \\
\hline 20 & Stachysemodi & 12.8 & 0.26 & 257.3 & 0.46 & 92 & 0.58 & 58 & 0.20 & 3 & 0.18 & 39 & 0.12 \\
\hline 21 & parviflora & 38.4 & 0.44 & 77 & 0.15 & 4 & 0.01 & 51 & 0.25 & 2 & 0.28 & 135 & 0.13 \\
\hline \multirow[t]{2}{*}{22} & Chenopodium & & & & & & & 96 & 0.28 & & 0.66 & & 1.13 \\
\hline & ambrosioides & 7 & 0.03 & 304.3 & 0.62 & 55 & 0.26 & & & 4 & & 163 & \\
\hline 23 & Artemesia absinthium & 14.3 & 0.21 & 138 & 0.31 & 67 & 0.43 & 25 & 0.08 & 6 & 0.75 & 52 & 0.06 \\
\hline 24 & Micromeria bioflora & 19.5 & 0.22 & 70.6 & 0.11 & 18 & 0.13 & 53 & 0.10 & 2 & 0.33 & 88 & 0.14 \\
\hline 25 & Salvia moorcoftiana & & 0.22 & 58.8 & 0.12 & 25 & 0.08 & 65 & 0.16 & 11 & 1.37 & 92 & 0.05 \\
\hline 26 & Onosma & 5.5 & 0.14 & 65.3 & 0.15 & 67 & 0.63 & 78 & 0.18 & 4 & 0.8 & 259 & 0.29 \\
\hline 27 & Isatiscostata & 11.7 & 0.16 & 38.1 & 0.04 & 48 & 0.19 & 169 & 0.51 & 5 & 1.66 & 327 & 0.19 \\
\hline
\end{tabular}

*TF: translocation factor 
Table 6. Concentration and comparison of PTEs in medicinal plant species of different countries

\begin{tabular}{|c|c|c|c|c|c|c|}
\hline S.No & Country & Medicinal plants & $\begin{array}{l}\text { Types of } \\
\text { PTEs }\end{array}$ & $\begin{array}{l}\text { Samples } \\
\text { analyzed }\end{array}$ & $\begin{array}{l}\text { PTEs } \\
\text { concentration mg } \\
\mathrm{kg}^{-1}\end{array}$ & References \\
\hline 1 & China & $\begin{array}{l}126 \text { Chinese Herbal } \\
\text { Medicines }\end{array}$ & $\begin{array}{l}\mathrm{Cd}, \mathrm{Cr} \\
\text { and } \mathrm{Pb}\end{array}$ & 334 & $\begin{array}{l}\text { Pb: } 0.04-8.15 \\
\text { Cd: } 0.02-4.35 \\
\text { Cr: } 0.01-21.0\end{array}$ & (Harris et al. 2011) \\
\hline 2 & India & $\begin{array}{l}\text { Bacopa monnieri, } \\
\text { Dioscorea } \\
\text { bulbifera and } \\
\text { Hippophae } \\
\text { rhamnoides, }\end{array}$ & $\begin{array}{l}\mathrm{Cr}, \mathrm{Pb} \\
\text { and } \mathrm{Cd}\end{array}$ & 7 & $\begin{array}{l}\mathrm{Pb}: 0.24-0.51 \\
\mathrm{Cd}: 0.18-0.5 \\
\mathrm{Cr}: 0.24-1.4\end{array}$ & (Sadhu et al. 2015) \\
\hline 3 & Egypt & Camomile & $\begin{array}{l}\mathrm{Cd} \text { and } \\
\mathrm{Pb}\end{array}$ & 70 & $\begin{array}{l}\text { Cd: } 0.004-0.13 \\
\text { Pb: } 0.06-5.9\end{array}$ & $\begin{array}{l}\text { (Dogheim et al. } \\
\text { 2004) }\end{array}$ \\
\hline 4 & Pakistan & Glycyrrhiza glabra $L$ & $\begin{array}{l}\mathrm{Cd}, \mathrm{Cr} \\
\text { and } \mathrm{Pb}\end{array}$ & 21 & $\begin{array}{l}\text { Cd: } 1.08 \\
\text { Cr: } 5.95 \\
\text { Pb: } 18.98\end{array}$ & (Hina et al. 2011) \\
\hline 5 & USA & $\begin{array}{l}\text { Asian and American } \\
\text { ginseng }\end{array}$ & $\begin{array}{l}\mathrm{Cd} \text { and } \\
\mathrm{Pb}\end{array}$ & 47 & $\begin{array}{l}\mathrm{Cd}:<0.05-259 \\
\mathrm{~Pb}: 3-2710\end{array}$ & $\begin{array}{l}\text { (Durgnat et al., } \\
\text { 2005) }\end{array}$ \\
\hline 6 & Ethiopia & 8 medicinal plant & $\begin{array}{l}\mathrm{Pb} \text { and } \\
\mathrm{Cd}\end{array}$ & 26 & $\begin{array}{l}\mathrm{Pb}: 0.17-98.2 \\
\mathrm{Cd}: 0.17-1.8\end{array}$ & $\begin{array}{l}\text { (Baye and Hymete, } \\
\text { 2010) }\end{array}$ \\
\hline 7 & Brazil & $\begin{array}{l}130 \text { samples of } 10 \\
\text { medicinal Plants }\end{array}$ & $\begin{array}{l}\mathrm{Cd} \text { and } \\
\mathrm{Pb}\end{array}$ & 130 & $\begin{array}{l}\text { Cd: } 0.22-0.74 \\
\mathrm{~Pb}: 2.0-11.7\end{array}$ & $\begin{array}{l}\text { (Caklasa and } \\
\text { Machoda 2004) }\end{array}$ \\
\hline 8 & $\begin{array}{l}\text { South } \\
\text { Africa }\end{array}$ & 8 medicinal plant & $\begin{array}{l}\mathrm{Cd} \text { and } \\
\mathrm{Pb}\end{array}$ & 37 & $\begin{array}{l}\mathrm{Cd} \text { : up to } 0.02 \\
\mathrm{~Pb}: \text { up to } 4.7\end{array}$ & (Street et al. 2008) \\
\hline 9 & Botswana & 12 medicinal plant & $\begin{array}{l}\mathrm{Cr}, \mathrm{Ni} \\
\text { and } \mathrm{Pb}\end{array}$ & 12 & $\begin{array}{l}\text { Pb: } 0.12-0.23 \\
\text { Cr: } 0.15-1.27 \\
\text { Ni: } 0.09-0.21\end{array}$ & $\begin{array}{l}\text { (Okatch et al. } \\
\text { 2012) }\end{array}$ \\
\hline 10 & Sudan & 33 medicinal plants & $\begin{array}{l}\mathrm{Cd} \text { and } \\
\mathrm{Pb}\end{array}$ & 33 & $\begin{array}{l}\text { Cd: } 0.8-187 \\
\mathrm{~Pb}: 2.6-481\end{array}$ & $\begin{array}{l}\text { (Ebrahim et al. } \\
\text { 2012) }\end{array}$ \\
\hline
\end{tabular}

Table 7. One-Way ANOVA of physical parameters and PTEs in degraded mining soils. 


\begin{tabular}{|c|c|c|c|c|c|c|}
\hline $\begin{array}{l}\text { Physio-chemical } \\
\text { parameters }\end{array}$ & Sources of variation & Sum of Squares & $\mathrm{Df}^{*}$ & Mean Square & $\mathrm{F}^{*}$ & Significance \\
\hline $\mathrm{PH}$ & $\begin{array}{l}\text { Between groups } \\
\text { Within groups } \\
\text { Total }\end{array}$ & $\begin{array}{l}36.1607 \\
3.9564 \\
40.1171\end{array}$ & $\begin{array}{l}1 \\
54 \\
55\end{array}$ & $\begin{array}{l}36.1607 \\
0.0733\end{array}$ & 494 & 0.00 \\
\hline EC & $\begin{array}{l}\text { Between groups } \\
\text { Within groups } \\
\text { Total }\end{array}$ & $\begin{array}{l}706704 \\
7438 \\
714142\end{array}$ & $\begin{array}{l}1 \\
54 \\
55\end{array}$ & $\begin{array}{l}706704 \\
138\end{array}$ & 5131 & 0.00 \\
\hline SOM & $\begin{array}{l}\text { Between groups } \\
\text { Within groups } \\
\text { Total }\end{array}$ & $\begin{array}{l}2.13721 \\
1.64701 \\
3.78422\end{array}$ & $\begin{array}{l}1 \\
54 \\
55\end{array}$ & $\begin{array}{l}2.13721 \\
0.03050\end{array}$ & 70.1 & 0.00 \\
\hline $\mathrm{Zn}$ & $\begin{array}{l}\text { Between groups } \\
\text { Within groups } \\
\text { Total }\end{array}$ & $\begin{array}{l}21005.2 \\
59418.1 \\
80423.3\end{array}$ & $\begin{array}{l}1 \\
54 \\
55\end{array}$ & $\begin{array}{l}21005.2 \\
1100.3\end{array}$ & 19.1 & 0.01 \\
\hline $\mathrm{Mn}$ & $\begin{array}{l}\text { Between groups } \\
\text { Within groups } \\
\text { Total }\end{array}$ & $\begin{array}{l}4168679 \\
521356 \\
4690035\end{array}$ & $\begin{array}{l}1 \\
54 \\
55\end{array}$ & $\begin{array}{l}4168679 \\
9655\end{array}$ & 432 & 0.00 \\
\hline $\mathrm{Pb}$ & $\begin{array}{l}\text { Between groups } \\
\text { Within groups } \\
\text { Total }\end{array}$ & $\begin{array}{l}275026 \\
653558 \\
928584\end{array}$ & $\begin{array}{l}1 \\
54 \\
55\end{array}$ & $\begin{array}{l}275026 \\
12103\end{array}$ & 22.7 & 0.00 \\
\hline $\mathrm{Ni}$ & $\begin{array}{l}\text { Between groups } \\
\text { Within groups } \\
\text { Total }\end{array}$ & $\begin{array}{l}3777549 \\
1021653 \\
4799203\end{array}$ & $\begin{array}{l}1 \\
54 \\
55\end{array}$ & $\begin{array}{l}3777549 \\
18920\end{array}$ & 200 & 0.00 \\
\hline $\mathrm{Cd}$ & $\begin{array}{l}\text { Between groups } \\
\text { Within groups } \\
\text { Total }\end{array}$ & $\begin{array}{l}481.341 \\
310.977 \\
792.317\end{array}$ & $\begin{array}{l}1 \\
54 \\
55\end{array}$ & $\begin{array}{l}481.341 \\
5.759\end{array}$ & 83.6 & 0.00 \\
\hline $\mathrm{Cr}$ & $\begin{array}{l}\text { Between groups } \\
\text { Within groups } \\
\text { Total }\end{array}$ & $\begin{array}{l}4239924 \\
4884548 \\
9124472\end{array}$ & $\begin{array}{l}1 \\
54 \\
55\end{array}$ & $\begin{array}{l}4239924 \\
90455\end{array}$ & 46.9 & 0.00 \\
\hline
\end{tabular}

Df: Degree of freedom

*F: Factor

Table 8. One-Way ANOVA of PTEs in medicinal plant species. 


\begin{tabular}{|c|c|c|c|c|c|c|}
\hline $\begin{array}{l}\text { Physio-chemical } \\
\text { parameters }\end{array}$ & Sources of variation & Sum of Squares & sf & Mean Square & F & Significance \\
\hline $\mathrm{Zn}$ & $\begin{array}{l}\text { Between groups } \\
\text { Within groups } \\
\text { Total }\end{array}$ & $\begin{array}{l}2.49 \\
1556.31 \\
1558.80\end{array}$ & $\begin{array}{l}1 \\
52 \\
53\end{array}$ & $\begin{array}{l}2.4919 \\
29.9291\end{array}$ & 0.08 & 0.77 \\
\hline Mn & $\begin{array}{l}\text { Between groups } \\
\text { Within groups } \\
\text { Total }\end{array}$ & $\begin{array}{l}101385 \\
125248 \\
226633\end{array}$ & $\begin{array}{l}1 \\
52 \\
53\end{array}$ & $\begin{array}{l}101385 \\
2409\end{array}$ & 42.1 & 0.00 \\
\hline $\mathrm{Pb}$ & $\begin{array}{l}\text { Between groups } \\
\text { Within groups } \\
\text { Total }\end{array}$ & $\begin{array}{l}100823 \\
211939 \\
312761\end{array}$ & $\begin{array}{l}1 \\
52 \\
53\end{array}$ & $\begin{array}{l}100823 \\
4076\end{array}$ & 24.7 & 0.00 \\
\hline $\mathrm{Ni}$ & $\begin{array}{l}\text { Between } \\
\text { Within group } \\
\text { Total }\end{array}$ & $\begin{array}{l}50712.3 \\
41626.6 \\
92338.9\end{array}$ & $\begin{array}{l}1 \\
52 \\
53\end{array}$ & $\begin{array}{l}50712.3 \\
800.5\end{array}$ & 63.3 & 0.00 \\
\hline $\mathrm{Cd}$ & $\begin{array}{l}\text { Between groups } \\
\text { Within groups } \\
\text { Total }\end{array}$ & $\begin{array}{l}239.781 \\
199.417 \\
439.198\end{array}$ & $\begin{array}{l}1 \\
52 \\
53\end{array}$ & $\begin{array}{l}239.781 \\
3.835\end{array}$ & 62.5 & 0.00 \\
\hline $\mathrm{Cr}$ & $\begin{array}{l}\text { Between groups } \\
\text { Within groups } \\
\text { Total }\end{array}$ & $\begin{array}{l}216109 \\
231782 \\
447891\end{array}$ & $\begin{array}{l}1 \\
52 \\
53\end{array}$ & $\begin{array}{l}216109 \\
4457\end{array}$ & 48.5 & 0.00 \\
\hline
\end{tabular}

*Df: Degree of freedom

*F: Factor

Table 9. Pearson correlation between the PTEs in degraded mining soils and medicinal plant species 


\begin{tabular}{|c|c|c|c|c|c|c|c|c|c|}
\hline Parameters & $\mathrm{Zn}$ & $\mathrm{Mn}$ & $\mathrm{Pb}$ & $\mathrm{Ni}$ & $\mathrm{Cd}$ & $\mathrm{Cr}$ & $\mathrm{pH}$ & $\mathrm{EC}$ & SOM \\
\hline \multicolumn{10}{|l|}{ Soil } \\
\hline $\mathrm{Zn}$ & 1.00 & -.149 & .163 & -.370 & .023 & .007 & .104 & $0.478^{*}$ & $0.398^{*}$ \\
\hline $\mathrm{Mn}$ & & 1.00 & -.186 & .338 & -.131 & .247 & .200 & -.135 & .203 \\
\hline $\mathrm{Pb}$ & & & 1.00 & $.453^{*}$ & .286 & .164 & -.005 & .363 & .056 \\
\hline $\mathrm{Ni}$ & & & & 1.00 & .295 & -.287 & -.031 & 0.235 & .160 \\
\hline $\mathrm{Cd}$ & & & & & 1.00 & .093 & -.241 & $0.433^{*}$ & -.236 \\
\hline $\mathrm{Cr}$ & & & & & & 1.00 & -.167 & 0.301 & .118 \\
\hline $\mathrm{pH}$ & & & & & & & 1.00 & .031 & -.172 \\
\hline E.C & & & & & & & & 1.00 & -.325 \\
\hline SOM & & & & & & & & & 1.00 \\
\hline \multicolumn{10}{|l|}{ Plants } \\
\hline Zn & 1.00 & -.045 & -.65 & -.246 & -.008 & -.050 & & & \\
\hline $\mathrm{Mn}$ & & 1.00 & -.312 & -.364 & .030 & -.293 & & & \\
\hline $\mathrm{Pb}$ & & & 1.00 & .331 & .162 & .167 & & & \\
\hline $\mathrm{Ni}$ & & & & 1.00 & .015 & .300 & & & \\
\hline $\mathrm{Cd}$ & & & & & 1.00 & -.309 & & & \\
\hline $\mathrm{Cr}$ & & & & & & 1.00 & & & \\
\hline
\end{tabular}

Figures 


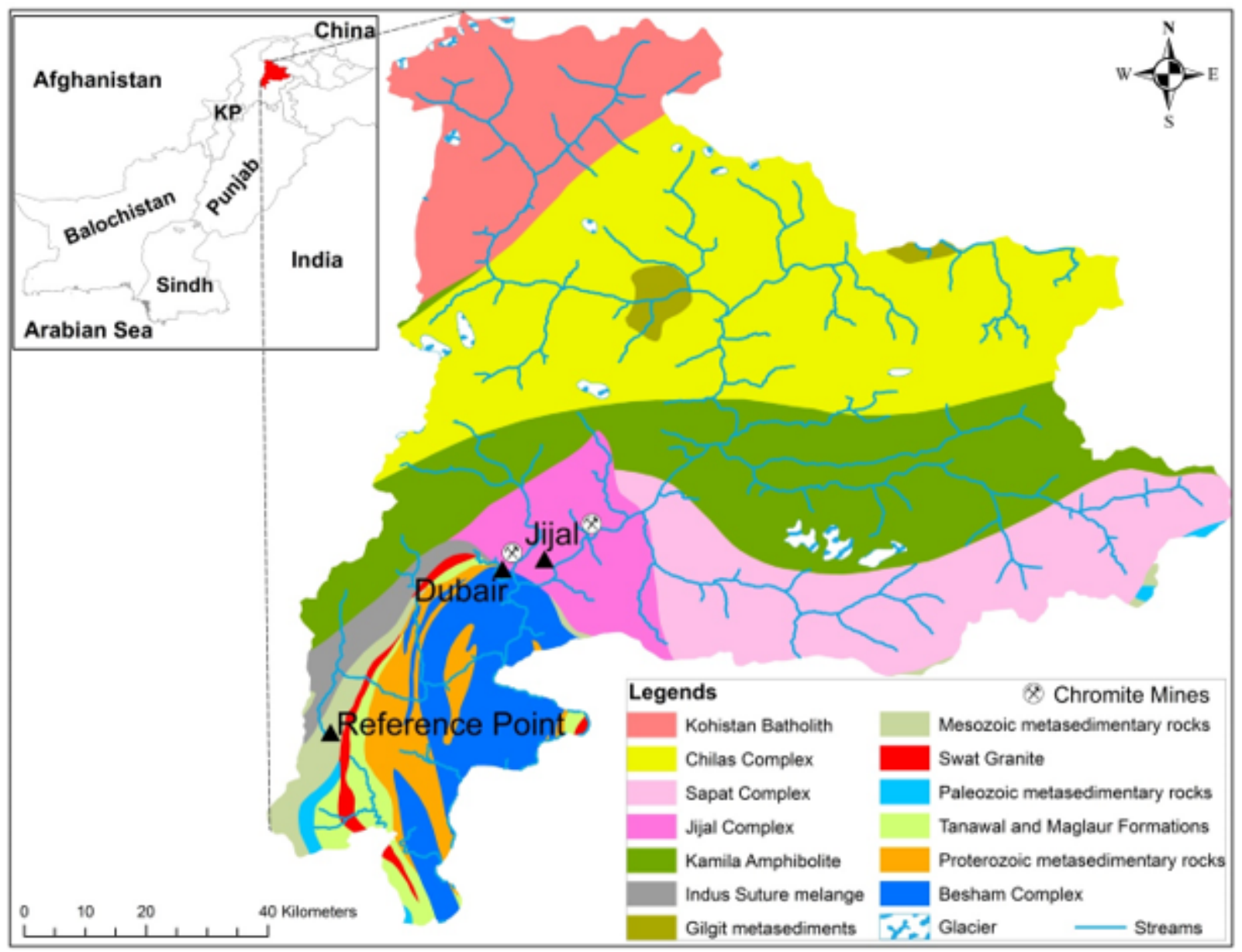

Figure 1

Location map of the study area showing the geology and sampling points.

\section{Supplementary Files}

This is a list of supplementary files associated with this preprint. Click to download.

- SuplimentarymaterialF.docx 